\title{
PODEJŚCIA DO BIĘDÓW I ICH POPRAWY WE WSPÓŁCZESNEJ GLOTTODYDAKTYCE
}

\begin{abstract}
Słowa kluczowe: błąd językowy, korektura błędów, informacja zwrotna, techniki korekty błędów, poprawność i płynność językowa, interjęzyk, fosylizacja, akwizycja językowa.

Streszczenie. Błędy są nieodłącznym elementem procesu uczenia się języków, ale także kontrowersyjnym zagadnieniem, szeroko dyskutowanym w środowisku badaczy zajmujących się akwizycją oraz dydaktyką językową. Niniejszy artykuł omawia zarówno pojęcie błędu, jego źródła i ogólną typologię, jak i sposoby traktowania błędu we współczesnej metodyce nauczania języków obcych. Przedstawione zostały eksplicytne oraz implicytne techniki dostarczania informacji zwrotnej i reakcji na błędy, popełniane przez uczących się języków obcych, a także rezultaty wybranych badań z zakresu analizy efektywności stosowania korektury i udzielania informacji zwrotnej w warunkach szkolnych.
\end{abstract}

\section{WSTĘP}

Błędy są nieodłącznym elementem procesu uczenia się języków. Stąd też samo zjawisko błędu, jak i przyczyny jego powstawania czy sposoby korektury ${ }^{2}$ są od dawna przedmiotem refleksji badaczy, zajmujących się akwizycją językową i dydaktyką języków obcych, a także praktyków - nauczycieli i uczniów. Stanowią rodzaj negatywnej informacji zwrotnej (negative evidence), która, obok kontaktu $\mathrm{z}$ odpowiednim materiałem językowym (ustnym lub pisemnym), będącym wzorem poprawności i akceptowalności w języku docelowym (positive evidence), a także produkcji językowej, umożliwiającej przetwarzanie danych językowych na poziomie semantycznym i syntaktycznym, należy do trzech, nie-

\footnotetext{
1'a.rabiej@uj.edu.pl; Centrum Języka i Kultury Polskiej w Świecie Uniwersytetu Jagiellońskiego; Katedra Języka Polskiego Jako Obcego; ul. Grodzka 64, 31-044, Kraków.

${ }^{2} \mathrm{Na}$ określenie interwencji pedagogicznej jaką jest poprawa błędów używamy w niniejszym artykule trzech terminów, które pojawiają się w literaturze przedmiotu i które traktujemy tutaj synonimicznie: poprawa, korekta (za W. Pawlakiem 2009) oraz korektura (za E. Zawadzką 2004).
} 
zbędnych w nauce języków obcych elementów (Gass 2003, za: M. Pawlakiem 2009, s. 313). Celem niniejszego artykułu jest omówienie, obecnych przede wszystkim we współczesnej glottodydaktyce, różnych podejść do definiowania i kategoryzacji błędów, sposobów postrzegania ich przydatności bądź szkodliwości dla procesu akwizycji językowej oraz typów reakcji na błędy jako rodzaju interwencji pedagogicznej, ale także działania, podejmowanego przez uczącego się języka drugiego/obcego.

\section{CHARAKTERYSTYKA BŁĘDÓW JĘZYKOWYCH RÓŻNORODNOŚĆ PODEJŚĆ I DEFINICJI}

W zależności od przyjętej teorii akwizycji języka, a w konsekwencji również metody nauczania, w różny sposób postrzegano rolę błędu w procesie opanowywania języka, odmiennie definiując także samo zjawisko błędu. Zdaniem E. Zawadzkiej (2004, s. 249-250; zob. także Lewicka-Mroczek 2009, s. 25-27), pojęcie błędu nie jest jednoznacznie zdefiniowane, ponieważ odnosi się je najczęściej do normy językowej, a ta ma szerokie znaczenie i może określać zarówno poziom zgodności wypowiedzi z systemem języka, jak i komunikacyjną i kulturową stosowność wypowiedzi. Dodatkową cechą normy jest także jej zmienność, ponieważ jest uwarunkowana kontekstem sytuacyjnym czy odmianą języka - mówionego bądź pisanego. Jak podaje Stownik dydaktyki języków obcych za błąd językowy (Szulc 1994, s. 40-41) należy uznać „niezamierzone przez mówiącego odchylenie (dewiacja) od reguł przewidzianych przez system danego języka lub od obowiązującej w ramach tego systemu normy językowej. (...) W zależności od tego, czy odchylenie dotyczy systemu języka, czy też normy, rozróżniamy: (a) błędy systemowe oraz (b) błędy poprawnościowe. Podczas gdy pierwsze z nich mogą powodować zaburzenia w bezpośredniej komunikacji językowej (np. niem. *[alə] alle 'wszyscy' zamiast [a:lə] (die) Aale 'węgorze'), pozostałe dotyczą tylko stopnia akceptabilności“. Elżbieta Zawadzka (2004, s. 251-252) proponuje odróżnić normę lingwistyczna od normy glottodydaktycznej, za tę drugą uważając nie wypowiedź obiektywnie odbiegającą od normy, lecz tę, która jest niezgodna ze standardami umiejętności przewidywanych dla danego poziomu uczenia się/nauczania języka. Norma glottodydaktyczna powinna, zdaniem autorki, uwzględniać czynniki rozwojowe, interjęzyk ucznia czy warunki nauczania. W literaturze psycholingwistycznej i glottodydaktycznej istnieje wiele klasyfikacji błędów językowych, tworzonych na podstawie zróżnicowanych kryteriów: typu materiału językowego czy podsystemu (błędy wymowy, pisowni, leksykalne, gramatyczne), komunikatywności przekazu (błę- 
dy lokalne i globalne), kryterium systematyczności (błędy systematyczne, sporadyczne, przejęzyczenia) czy źródła błędów (błędy jako rezultat interferencji zewnątrz- bądź wewnątrzjęzykowej, błędy jako efekt sposobu uczenia się lub nauczania, błędy strategiczne) (Komorowska 2002, s. 176-177; H. D. Brown 2007; Lewicka-Mroczek 2009). Jedną z klasycznych typologii błędów, dających się zauważyć i opisać w procesie akwizycji języka drugiego, zaproponował S. Corder (1971, za: H. D. Brownem 2007, s. 260-263), który wyróżnił dwie nadrzędne kategorie błędów: jawne (overt errors), widoczne na poziomie zdania i wyrażające się w niepoprawnych formach gramatycznych oraz błędy ukryte (covert errors), dostrzegalne na poziomie dyskursu, w sytuacji braku stosowności komunikacyjnej wypowiedzi. Corder, dokonując identyfikacji błędów językowych, opisał także cały proces refleksji nad interjęzykiem użytkownika języka drugiego/obcego. Przedstawiony tu rysunek (schemat 1), zaczerpnięty z pracy H. Douglasa Browna (2007, s. 261), dobrze ilustruje ten proces, pokazując różne możliwości wyjścia z sytuacji, w której powstały zdania niepoprawne i uwzględniając zarówno sukces etapu przejściowego na drodze tworzenia wypowiedzi w języku docelowym, jak i porażkę w tym zakresie (użytkownik dysponuje wyłącznie błędną i niezrozumiałą formą komunikatu). W przypadku każdego z omawianych tu typów błędów (jawnych i ukrytych) jesteśmy w stanie stworzyć rekonstrukcję poprawnej wypowiedzi w języku docelowym i porównać ją z wersją pierwotną i językowo zaburzoną, by w następnej kolejności zobaczyć i opisać stosowne różnice między nimi (schemat 1: wyjście 1. i 2.). W przypadku, gdy dodatkowo znany jest również język pierwszy uczącego się, wskaźnikiem poziomu interferencji, ale także refleksji nad językiem może być stosowanie przez uczącego się strategii tłumaczenia z języka ojczystego na język drugi/obcy (schemat 1: punkt H).

Proces rekonstrukcji, o którym mowa, jest jednak możliwy wyłącznie wtedy, gdy dana wypowiedź da się w sposób wiarygodny zinterpretować. W niektórych przypadkach błędy nie poddają się jakiejkolwiek analizie ze względu na niemożność intepretacji wypowiedzi (schemat 1: wyjście 3.)

Model Cordera pozwala, w sposób uproszczony, zarówno badaczom, jak i nauczycielom śledzić proces powstawania interjęzyka osoby uczącej się języka drugiego/obcego, pozostawiając jednak szczegółowy opis niepoprawnych form wypowiedzi innym podejściom błędologicznym. 


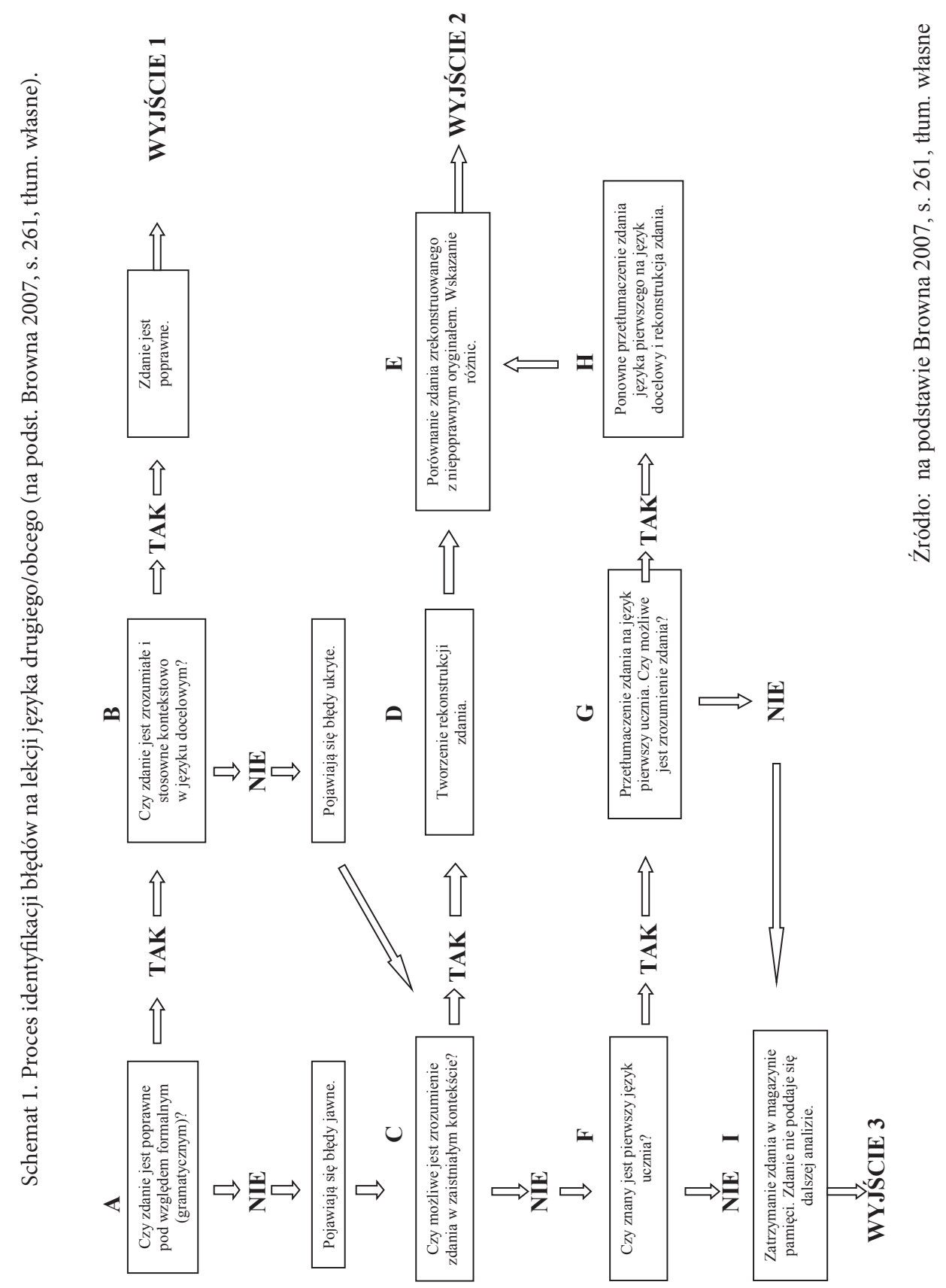




\section{BLĄD JAKO NIEPOŻĄDANY GOŚĆ VS BLĄD JAKO SPRZYMIERZENIEC}

Poglądy na temat roli błędu w procesie uczenia się języka ewoluowały wraz z myślą lingwistyczną oraz zmianami metodologicznymi w obrębie glottodydaktyki jako nauki. W okresie dominacji językoznawstwa strukturalnego i psychologii behawioralnej w latach 60. ubiegłego wieku, błędy językowe traktowane były najczęściej jako rezultat wpływów z języka pierwszego ucznia i w tym znaczeniu uważano je za zjawisko niepożądane, wymagające natychmiastowej korektury ze względu na ryzyko utrwalenia złych nawyków. Taki sposób myślenia widoczny jest w lingwistycznej koncepcji kontrastywności (The Contrastive Analysis Hypothesis) Fries (1952) i Lado (1957), w myśl której porównywanie języków ma umożliwiać przede wszystkim przewidywanie błędów, a w konsekwencji pozwolić uczącym się unikać miejsc trudnych poprzez mechaniczne opanowywanie wypowiedzi modelowych, pozbawionych ryzyka powstania błędu. Z krytyki hipotezy kontrastywności zrodziła się teoria wpływów międzyjęzykowych (cross-linguistic influence), która przeniosła punkt ciężkości z przewidywania błędów na badanie wpływów zarówno wewnatrz-, jak i zewnattrzjęzykowych oraz wyjaśnianie przyczyn powstawania form niepoprawnych.

Wraz z pojawieniem się kognitywnej teorii akwizycji językowej zmieniło się również postrzeganie samych uczących się języka, już nie jako twórców niedoskonałych form językowych, lecz jednostki twórcze i inteligentne, które przetwarzają informacje na podstawie danych wejściowych oraz kontekstu, generując wiedzę na temat funkcjonowania języka i testując hipotezy związane z jego użyciem w danej sytuacji. Testowanie odbywa się metodą prób i błędów, a proces opanowywania języka zakłada etap przejściowy, określany za Selinkerem (1972) mianem interjęzyka, gdy produkcja językowa jest na etapie poszukiwania normy języka docelowego i jest specyficzna dla każdego z użytkowników języka (idiosyncratic dialect). Twórczy i aktywny uczący się jest niewątpliwie pozytywnym elementem koncepcji interjęzyka, niemniej, zakładany w tej koncepcji czasowy charakter błędu i jego samoistne zanikanie jest z punktu widzenia dydaktyki kontrowersyjne, ponieważ ogranicza lub nawet wyklucza sensowność jakiejkolwiek poprawy błędów ze strony nauczyciela czy rówieśników. Ponadto, może prowadzić do zamrożenia istniejącej kompetencji przejściowej (fosylizacji) i utrwalenia określonych błędów.

Ewolucja poglądów na temat błędów, doprowadziła do podejścia znanego jako error analysis, zajmującego się znaczeniem błędu w procesie akwizycji języków i zaowocowała przekonaniem, że błędy językowe są świadectwem zachodzącego procesu uczenia się a - jako zjawisko - są korzystne z punktu widzenia 
uczniów, ponieważ pomagają zweryfikować hipotezy na temat działania języka i form jego użycia. Są również korzystne z punktu widzenia nauczycieli - informują bowiem o procesach myślowych ucznia i dowodzą aktywnego przetwarzania informacji językowej przez niego przy odpowiednio intensywnym kontakcie $\mathrm{z}$ językiem.

\section{KOREKTA BLĘDÓW JĘZYKOWYCH JAKO ELEMENT DZIAŁAŃ DYDAKTYCZNYCH}

Patrząc na zagadnienie korekty błędów z perspektywy glottodydaktyki historycznej można wyróżnić dwa podstawowe nurty - akceptujący błąd językowy oraz postrzegający błąd negatywnie (Komorowska 2002). Do drugiego nurtu należy włączyć przede wszystkim podejście audiolingwalne, traktujące błąd jako informację o źle prowadzonym procesie nauczania, dlatego z założenia unikające błędu od początku pracy z językiem poprzez wielokrotne powtórzenia wzorcowych wypowiedzi i ich zapamiętywanie. Nurt akceptujący reprezentują natomiast: podejście naturalne (the Natural Approach), autorstwa T. Terella i S. Krashena (1983) oraz metoda zespołowego uczenia się (Community Language Learning). Zarówno stosunek do błędu, jak i opinia na temat włączania w proces uczenia się/nauczania korekty błędów wiąże się z nierozstrzygniętym w dydaktyce językowej dylematem - czy należy koncentrować się na poprawności językowej czy na płynności? $\mathrm{O}$ ile w pierwotnej wersji nurtu akceptującego nie dostrzegano potrzeby wprowadzania informacji zwrotnej i korekty błędów, traktując błędy jako naturalny element procesu uczenia się, które przy dostatecznej ekspozycji na język zanikną, o tyle obecnie metody interakcyjne (podejście komunikacyjne, podejście działaniowe) zakładają potrzebę zachowania równowagi pomiędzy zwracaniem uwagi na formę, a co za tym idzie także na korektę form błędnych (focus on form) a naturalnym, płynnym sposobem uczenia się języka, skoncentrowanym na znaczeniu (focus on meaning) (Janowska, Rabiej, 2014). Jak podkreśla M. Pawlak (2009, s. 328) status korekty językowej jako ważnego narzędzia, które ułatwia opanowanie języka, stymuluje negocjowanie formy i umożliwia wewnętrzne porównania został wzmocniony hipotezą interakcyjną (interacion hypothesis) Longa (1983), hipotezą produkcji językowej (output hypothesis), zaproponowaną przez Swain (1985) oraz hipotezą świadomego postrzegania (noticing hypothesis) Schmidta (1990). We wczesnej wersji hipotezy interakcyjnej, M. H. Long zdecydowanie podkreślał, że negocjowanie znaczeń w interakcji ułatwia zrozumienie materiału językowego. To twierdzenie zostało uzupełnione przez Swain, która - prowadząc badania nad programami immersyjnymi w Kanadzie - zwracała uwagę, iż dobre opanowanie języka docelowego wymaga nie tylko tworzenia zrozumiałych wy- 
powiedzi, ale także takich, które spełniają kryterium poprawności, są logiczne i stosowne w określonym kontekście. Nieświadome uczenie się, pozbawione informacji zwrotnej i korektury form niepoprawnych stało się przedmiotem krytyki hipotezy świadomego postrzegania, wedle której ,przyswojenie języka obcego wymaga zwrócenia uwagi na określone formy, tak, aby uczący się mógł porównać zamierzone lub wyartykułowane wypowiedzi z ich poprawnymi odpowiednikami i w ten sposób dostrzec luki w swojej wiedzy językowej (notice the gap). To z kolei przyczyniło się do powstania zmodyfikowanej wersji hipotezy interakcyjnej (Long 1996), która wciąż podkreślała rolę nogocjacji znaczeń w segmentacji materiału językowego (co ułatwia zrozumienie), ale też wskazywała na jej bezpośredni wpływ na rozwój języka pośredniego przez dostarczanie informacji zwrotnej na temat poprawności czy akceptowalności wypowiedzi i stymulowanie ich modyfikacji, tak, aby były one zgodne z normami języka docelowego" (Pawlak, 2009, s. 315; por. Biedroń 2009). Przywoływane tu modele teoretyczne znalazły potwierdzenie w wynikach badań empirycznych, dotyczących akwizycji wybranych form językowych. Dowiodły, że rodzaj interakcji szkolnej, prowadzący do korektury błędów, ma pozytywny wpływ na opanowanie form językowych zarówno jako wiedzy świadomej (eksplicytnej), deklaratywnej, opartej na świadomej znajomości reguł, jak i nieświadomej (implicytnej), o charakterze proceduralnym, podlegającej procesowi interioryzacji struktur językowych (Mackey 2007; Ellis 2007, 2009, za: M. Pawlakiem 2009, s. 316). Mimo dominującej obecnie wśród badaczy oraz praktyków opinii o istotnej roli korektury błędów w procesie nauki języka, niektórzy autorzy kwestionują jej skuteczność, sceptycznie odnosząc się do rezultatów przywołanych badań i modeli teoretycznych (zob. np. Truscott 1996, 1999). Niniejszy artykuł opiera się jednak na założeniu, iż korekta błędów może przyczynić się do optymalizacji procesu nauczania, zwłaszcza, gdy jest prowadzona z wykorzystaniem odpowiednich technik dostarczania informacji zwrotnej (zob. punkt 5.), stąd też nie omawiamy szczegółowo poglądów przeciwstawnych, sygnalizując tylko ich istnienie.

\section{TECHNIKI DOSTARCZANIA INFORMACJI ZWROTNEJ}

Jednym z pierwszych modeli dostarczania informacji zwrotnej i reakcji na błąd językowy w warunkach szkolnych była propozycja N. A. Vigila oraz J. W. Ollera (1976, za: H.D. Brownem 2007, s. 273-275). Reakcje na błąd można sklasyfikować, zdaniem twórców modelu, w dwojaki sposób: jako rodzaj interakcji między nadawcą a odbiorcą o charakterze afektywnym (bazuje na sygnałach niewerbalnych) oraz interakcji odwołującej się do sfery kognitywnej (dźwięki, struktury, dyskurs), przy czym oba typy reakcji zachodzą równocześnie. Niemniej, 
tylko kognitywny typ informacji zwrotnej determinuje poziom świadomego stosowania struktur językowych. Brown (tamże, s. 273) ujmuje ten proces w sposób metaforyczny, ilustrując koncepcję Vigila i Ollera poprzez sygnalizator świetlny.

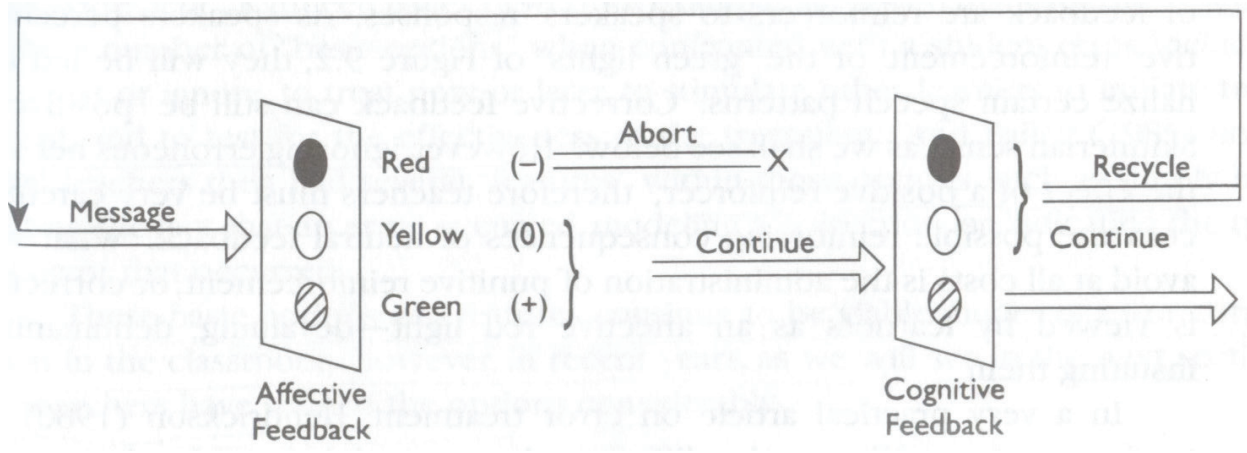

Schemat 2. Model afektywnego i kognitywnego typu informacji zwrotnej (źródło: Brown 2007, s. 273).

Zielone światło symbolizuje typ reakcji, który pozwala nadawcy kontynuować wypowiedź, podczas gdy światło czerwone każe zarzucić nadawanie komunikatu w istniejącej formie. Żółte światło odwołuje się do wywołania u nadawcy poczucia niepełnej stosowności stworzonego komunikatu i konieczności jego modyfikacji. Optymalna ilość informacji zwrotnej decyduje o jej efektywności - nadmiar negatywnych reakcji ze strony nauczyciela: wtrącenia, korekty i przesadna koncentracja na błędnych formach (światło czerwone) może skutkować zaprzestaniem podejmowania prób komunikacji i uczestnictwa $\mathrm{w}$ interakcji w klasie. Zbytnia pobłażliwość wobec form niepoprawnych (światło zielone) niesie zaś ryzyko utrwalenia błędów językowych i może prowadzić do fosylizacji. Rolą nauczyciela jest utrzymanie odpowiedniej równowagi pomiędzy pozytywnym i negatywnym typem reakcji na błąd - taka liczba zielonych światel, jaka jest potrzebna, by podtrzymywać gotowość komunikacyjną uczniów i taka liczba czerwonych świateł, jaka jest potrzebna, by sterować uwagą nadawcy i umożliwić mu zauważenie luk w swojej produkcji językowej, a następnie podjęcie próby przeformułowania wypowiedzi w zgodzie z normą języka docelowego.

M. Pawlak (2006), na wzór typologii błędów Cordera (zob. punkt 2.), dokonuje rozróżnienia na jawny (bezpośredni, o charakterze eksplicytnym) i ukryty (implicytny, niebezpośredni) typ informacji zwrotnej. Jawny rodzaj reakcji na błąd wiąże się z formalnym typem instrukcji klasowej i dotyczy lekcji skoncentrowanej na poprawności. Jest rodzajem interwencji pedagogicznej, której celem jest zwracanie uwagi uczących się na specyficzne, błędne formy, pojawiające się w komunikacji. Ukryty typ informacji zwrotnej pojawia się częściej na lekcjach skoncentrowanych bardziej na treści i znaczeniu czy ćwiczeniu płynności wypowiedzi. Zdaniem autora (tamże, s. 306), wyróżnionych tu sposobów reakcji na błąd nie należy postrzegać w sposób przeciwstawny, lecz traktować je jako rodzaj 
kontinuum, gdzie płynnie przechodzi się od stosowania technik bardziej eksplicytnych po te o charakterze implicytnym. Ukryty rodzaj informacji zwrotnej bazuje na dyskretnym modelowaniu komunikatów uczniowskich na wzór, postulowanego przez socjokulturową teorię akwizycji językowej (Lantolf, 2006), budowania rusztowania (scaffolding), a więc takiego sposobu przeformułowywania błędnych form językowych, który przypomina rodzaj naturalnej interakcji między matką a dzieckiem, odbywającej się w sprzyjającej, życzliwej atmosferze i umożliwiającej konstruowanie wypowiedzi z pomocą bardziej zaawansowanych rozmówców.

Przykładowy dialog, ilustrujący proces budowania rusztowania w procesie akwizycji językowej (oprac. własne):

Małgosia: Mamo! Mamo! Upadało się!

Mama: Co się stato? Co upadto?

Malgosia: Tu, tu! Upadało się!

Mama: Oj, upadto...?

Malgosia: Taak...

Mama: A co upadlo?

Malgosia: Kótko.

Mama: Kótko upadto?

Małgosia: Taak.. kótko ... upadto.

Mama: No tak. Kótko upadto. Nic nie szkodzi. Zaraz je podniesiemy. Antosiu, pomożesz nam? (...)

Taki sposób korektury błędów stwarza bardzo dobre warunki dla prawdziwego odkrywania reguł języka, istniejących już w umyśle użytkownika języka docelowego, a także poszerzania ich o nowe elementy czy kontekst użycia. Bazuje przy tym na naturalnym języku, który w rzeczywistej komunikacji obfituje w powtórzenia i przekształcenia.

Najbardziej rozpowszechniony inwentarz technik dostarczania informacji zwrotnej uczącym się został opracowany przez duet autorów, zajmujących się badaniem kategorii błędu i reakcji na błąd w kanadyjskich programach immersyjnych w grupie uczniów w wieku 9-11 lat: Roya Lystera i Leilę Rantę (1997, za: H.D. Brownem, 2007; P.M. Lightbown, N. Spadą, 2011 i M. Pawlakiem, 2013). Techniki, o których mowa, tworzą listę sześciu podstawowych sposobów reakcji na błąd (zob. także H. Komorowska 2002, s. 176-181). Należą do nich: (a) podanie poprawnej formy (explicit correction), (b) przeformułowanie (recast), (c) prośba o wyjaśnienie (clarification request), (d) wskazówka metajęzykowa (metalinguistic feedback), (e) elicytacja (elicitation), (f) powtórzenie (repetition $)^{3}$. Podanie poprawnej formy to rodzaj korekty bezpośredniej, która polega na wskazaniu błędnie użytej formy i dostarczeniu wzoru poprawnościowego, np.:

${ }^{3}$ Wszystkie przykłady zastosowania wyróżnionych tu technik dostarczania informacji zwrotnej w interakcji uczeń-nauczyciel zostały opracowane przez autorkę niniejszego artykułu. 
Agnieszka Rabiej

Student: $W$ weekend chodzitem do Warszawy.

Nauczyciel: Nie , chodzilem" do Warszawy, ale „pojechatem" do Warszawy. „Pojechatem” pociagiem albo autobusem...

Przeformułowanie jest sposobem na powtórzenie całości bądź części wypowiedzi, ale bez fragmentu niepoprawnego, jak w poniższym przykładzie:

Student: Mam dwa siostry i jednego brata.

Nauczyciel: Mam dwie siostry i jednego brata.

Student: Tak, mam dwie siostry i jednego brata.

Jak ocenia Pawlak (2013, s. 314), ,słabością takich technik jest to, że uczeń może powtórzyć poprawną formę nie rozumiejąc, na czym polegał błąd, podczas gdy przeformułowanie może być zinterpretowane jako komentarz a nie negatywna informacja zwrotna. Alternatywą jest podanie wskazówki dotyczącej wystąpienia błędu i jego charakteru (prompt), co nakłada na ucznia obowiązek podjęcia próby samodzielnej jego korekty $i$ jest wstępem do negocjowania formy (negotiation of form)". Trzecią z rzędu techniką reakcji na błąd, wymienioną przez Lystera i Rantę (1997) jest prośba o wyjaśnienie, której celem jest doprecyzowanie formy i treści komunikatu, a kolejną - wskazówka metajęzykowa, uważana przez specjalistów za najbardziej skuteczny rodzaj informacji zwrotnej.

Przykład prośby o wyjaśnienie (w połączeniu z innymi technikami):

Nauczyciel: Jak często chodzisz do kina?

Student: Zawsze dwa tygodnie.

Nauczyciel: Dwa tygodnie? Jak to dwa tygodnie? (clarification request)

Student: Jeden tydzień tak, jeden tydzień nie.

Nauczyciel: Chodzisz co dwa tygodnie? (recast)

Student: Co dwa tygodnie, tak. (repetition)

Przykład wskazówki metajęzykowej:

Student: Nie podoba mi się ten zimny pogoda w Polsce.

Nauczyciel: „Pogoda” ma rodzaj żeński, bo kończy się na-a. Jak mówimy, kiedy zaimek ma rodzaj żeński?

Student: Ta pogoda?

Nauczyciel: Bardzo dobrze. A przymiotnik? Jaka pogoda?

Student: Zimna pogoda.

Elicytacja jest sposobem na sprowokowanie ucznia do samodzielnego przeformułowania niepoprawnej wypowiedzi, jak w poniższym przykładzie:

Student: Jakie masz ubrania?

Nauczyciel: Nie ,Jakie...?”, ale „Co masz...”

Student: , Co masz ubrania...?”

Nauczyciel: Nie ubrania. Ja mam na sobie dżinsy. „A ty co masz .....?” 
Student: Co masz na sobie?

Nauczyciel: Tak. „Co masz na sobie?”. Ja mam na sobie dżinsy. A ty Tom? Co masz na sobie?

Natomiast ostatnia z wymienionych wcześniej technik to powtórzenie przez nauczyciela błędnego komunikatu, któremu często towarzyszy wzosząca intonacja, sugerująca nieprawidłowe użycie danej formy przez ucznia.

Przykład zastosowania techniki powtórzenia:

Student: Nie wiem jego nazwisko.

Nauczyciel: Nie wiem? Nie znam. Nie znam jego nazwiska

Korekta, jakiej może dokonać uczący się w reakcji na otrzymaną od nauczyciela informację zwrotną, przybiera w propozycji Lystera i Ranty (1997) trzy formy: natychmiastowej absorbcji poprawnej formy (uptake), poprawki (repair - tu możliwa jest także korekta rówieśnicza) oraz powtórzenia poprawnej formy (repetition) i stopniowego włączania jej do swoich wypowiedzi (Brown 2007, s. 278). Zależność sukcesu w nauce języka docelowego od stosowania korektury błędów można badać w odniesieniu do rezultatów testów, ale także poprzez obserwację procesu monitorowania swoich wypowiedzi przez uczniów (samodzielna identyfikacja błędu, refleksja nad nim i autokorekta). „Istotnym czynnikiem jest też związek pomiędzy natychmiastową reakcją ucznia na dokonywaną korektę, a opanowaniem danej struktury w dłuższym czasie, gdyż, jak pokazały niektóre badania (np. Loewen i Philp 2006), choć autokorekta lub powtórzenie poprawnej formy nie stanowi dowodu na to, że została ona przyswojona, to jednak rola interwencji w tym zakresie może być pozytywna (Pawlak 2013, s. 319-320; por. D. Witkowski 2005)".

\section{PODSUMOWANIE}

Podejścia do błędów oraz poprawy błędów ewoluowały w glottodydaktyce na przestrzeni ostatnich kilkudziesięciu lat. Było to uwarunkowane zmieniającymi się koncepcjami ujmowania procesu akwizycji językowej oraz postulowanymi w danym momencie metodami uczenia się i nauczania. Najbardziej aktualne ujęcie tego zagadnienia każe postrzegać błąd i jego poprawę za jedno ze źródeł postępów w nauce języka docelowego. Stanowią one bowiem sposobność do nauki - umożliwiają uczącym się zauważenie niedoskonałości w ich interjęzyku (luki, braki, niedociągnięcia), stymulują świadomy, bądź nieświadomy proces pokonywania trudności na drodze opanowywania nowych umiejętności i zachęcają do modyfikacji własnej wypowiedzi, wspomagają refleksję nad językami (ojczystym i docelowym - jednym lub kilkoma). Informacja zwrotna, udzielana zwłaszcza 
w ćwiczeniach komunikacyjnych, wspomaga proces zdobywania wiedzy proceduralnej i ułatwia dostęp do tych cech języka, które są już częścią wiedzy implicytej uczącego się. Jak podkreśla M. Pawlak (2013, s. 307), należy jednak pamiętać, że „(..) sam fakt poprawienia błędu wcale nie musi się przekładać na rozwój wiedzy językowej, a przydatność korekty zależy od tego, w jaki sposób jest ona przeprowadzona, w jakich okolicznościach ma to miejsce i w jakim stopniu uczący się potrafią z niej skorzystać". Pamiętając zarówno o tych ograniczeniach, jak i przywoływanych w niniejszym artykule rezultatach badań, należy uznać i samo zjawisko błędu, i jego korekturę za potrzebne i pożyteczne narzędzia interwencji pedagogicznej oraz autorefleksji i autokorekty uczniowskiej.

\section{BIBLIOGRAFIA}

Biedroń A., 2009, Czy neurologia ma zastosowanie w dydaktyce nauczania języków obcych?, w: M. Pawlak, M. Derenowski, B. Wolski (red.), Problemy wspótczesnej dydaktyki języków obcych, Poznań-Kalisz, s. 29-40.

Brown H.D., 2007, Principles of Language Learning and Teaching, Pearson Education.

Corder S., 1971, Idiosyncratic dialecs and error analysis, „International Review of Applied Linguistics", nr 5, s. 147-159.

Ellis R., 2007, The differential effect of corrective feedback on two grammatical structures, w: A. Mackey (red.), Conversational interaction in second language acquisition, Oxford: Oxford University Press, s. 339-360.

Ellis R., 2009, Corrective feedback and teacher development, „L2 Journal”, nr 1, s. 3-18.

Fries C., 1952, The structure of English, New York: Harcourt, Brace \& World.

Gass S., 2003, Input and interaction, w: C.J. Doughty, M.H. Long (red.), The Handbook of Second Language Acquisition, s. 224-255.

Janowska I., Rabiej A., 2014, Zadanie jako forma wspierania refleksyjnego nauczania gramatyki, w: „Neofilolog”, nr 43/2, tom: Podsystemy języka w praktyce glottodydaktycznej, pod red. M. Gajosa, Poznań-Lódź, s. 143-154.

Kita M., Czempka-Wiewióra M., Ślawska M. (red.), Błąd językowy w perspektywie komunikacyjnej, Seria: „Językoznawstwo”, nr 4, Katowice.

Komorowska H., 2002, Metodyka nauczania języków obcych, Warszawa.

Krashen S., Terrell T., 1983, The natural approach: Language acquisition in the classroom, Oxford: Pergamon Press.

Lado R., 1957, Linguistics across cultures, Ann Arbor: University of Michigan Press.

Lantolf J., 2006, Sociocultural Theory and L2: State of the art, „Studies in Second Lnaguage Acquisition", nr 28, s. 67-109.

Lewicka-Mroczek E., 2009, Błą językowy na lekcji języka obcego. Sposoby reagowania i terapii, w: H. Komorowska (red.), Skuteczna nauka języka obcego. Struktura i przebieg zajęć językowych, Warszawa, s. 25-36.

Lightbown P. M., Spada N., 2011, How Languages are Learned, Oxford: Oxford University Press.

Loewen S., Philp J., 2006, Recasts in the adult English L2 classroom: Characteristics, explicitness and effectiveness, „Modern Language Journal”, $\mathrm{nr}$ 90, s. 536-556.

Long M. H., 1983, Linguistic and conversational adjustments to non-native speakers, „Studies in Second Language Acquisition", nr 5, s. 177-193. 
Long M. H., 1996, The role of the linguistic environment in second language acquisition, w: W. Richie, T. Bahatia (red.), Handbook of research on second language acquisition, s. 413-468.

Mackey A. (red.), 2007, Conversational interaction in second language acquisition, Oxford: Oxford University Press.

Lyster R., Ranta L., 1997, Corrective feedback and learner uptake: Negotiation of form in communicative classrooms, „Studies in Second Language Acquisition”, nr 19, s. 37-66.

Pawlak M., 2006, The Place of Form-Focused Instruction in the Foreign Language Classroom, Kalisz-Poznań.

Pawlak M., 2009, Rola nauczyciela w kształtowaniu procesów interakcyjnych w klasie językowej, w: M. Pawlak, A. Mystkowska-Wiertelak, A. Pietrzykowska (red.), Nauczyciel języków obcych dziś i jutro, Poznań-Kalisz, s. 311-337.

Pawlak M., 2013, Czynniki warunkujace występowanie i skuteczność korekty błędów językowych podczas mówienia, w: M. Pawlak (red.), Mówienie w języku obcym: skuteczne uczenie się, nauczanie i ocenianie, Poznań-Kalisz-Konin, s. 305-326.

Schmidt R., 1990, The role of consciousness in second language learning, „Applied Linguistics”, nr 11, s. 17-46.

Selinker L., 1972, Interlanguage, „International Review of Applied Linguistics“, nr 10, s. 201-231.

Swain M., 1985, Communicative competence: Some roles of comprehensible input and comprehensible output in its development, w: S. Gass, C. Madden (red.), Input in Second Language Acquisition, Rowley, MA: Newbury House, s. 235-253.

Szulc A., 1994, Stownik dydaktyki języków obcych, Warszawa.

Truscott J., 1996, Review article: The case against grammar correction in L2 writing classes, „Language Learning", nr 46, s. 327-369.

Truscott J., 1999, What's wrong with oral correction?, „Canadian Modern Language Review”, nr 55, s. 437-456.

Vigil N., Oller J., 1976, Rule fossilization: A tentative model, „Language Learning“, nr 26, s. $281-295$.

Zawadzka E., 2004, Nauczyciele języków obcych w dobie przemian, Kraków.

Agnieszka Rabiej

\section{INVESTIGATING DIFFERENT APPROACHES TO ERRORS AND CORRECTION IN THE CONTEPORARY GLOTTODIDACTICS}

Keywords: errors and correction, error analysis, feedback, categories of error treatment, focus on form vs focus on meaning, interlanguage, fossilization, second language acquisition.

Summary. Learning languages is a process that involves the making of misteakes and has been a controversial issue in second language acquisition area of study and research. The aim of the paper is to examine such aspects of second language acquistion as error treatment in the language classroom as well as the provision of negative evidence nad corrective feedback (feedback types and learner responses to feedback) and effectiveness of form-focused instruction. 